\title{
Review Article \\ Thyroid Hormone and Wound Healing
}

\author{
Joshua D. Safer \\ Section of Endocrinology, Boston University School of Medicine, Room M-1016, 715 Albany Street, Boston, MA 02118, USA \\ Correspondence should be addressed to Joshua D. Safer; jsafer@bu.edu \\ Received 29 January 2013; Accepted 9 February 2013 \\ Academic Editor: Constantinos Pantos \\ Copyright (c) 2013 Joshua D. Safer. This is an open access article distributed under the Creative Commons Attribution License, \\ which permits unrestricted use, distribution, and reproduction in any medium, provided the original work is properly cited.

\begin{abstract}
Although thyroid hormone is one of the most potent stimulators of growth and metabolic rate, the potential to use thyroid hormone to treat cutaneous pathology has never been subject to rigorous investigation. A number of investigators have demonstrated intriguing therapeutic potential for topical thyroid hormone. Topical $\mathrm{T}_{3}$ has accelerated wound healing and hair growth in rodents. Topical $\mathrm{T}_{4}$ has been used to treat xerosis in humans. It is clear that the use of thyroid hormone to treat cutaneous pathology may be of large consequence and merits further study. This is a review of the literature regarding thyroid hormone action on skin along with skin manifestations of thyroid disease. The paper is intended to provide a context for recent findings of direct thyroid hormone action on cutaneous cells in vitro and in vivo which may portend the use of thyroid hormone to promote wound healing.
\end{abstract}

\section{Introduction}

Despite early observation of cutaneous pathology associated with thyroid disease $[1,2]$, research on the topic remains sparse. Direct thyroid hormone action has been demonstrated on cutaneous biology including on the epidermis, dermis, and hair. In addition, autoimmune diseases with cutaneous manifestations may be associated with thyroid dysfunction (which may be autoimmune in etiology itself).

The lack of investigation into cutaneous responses to thyroid hormone might be attributed to the fact that mostcases of thyroid disease are controlled with existing medication. However, there is a slowly evolving literature that suggests that the thyroid hormone pathway is integral to cutaneous physiology and that manipulation of the thyroid hormone pathway in skin could be used to treat cutaneous disease.

The skin manifestations of hypothyroidism have been described since the 1800 s. Indeed, the observation associating hypothyroidism with the skin [1] predates the classic publication associating hypothyroidism with the thyroid [2].

Thyrotoxicosis is also associated with cutaneous manifestations [3]. Although autoimmune-associated manifestations may be specific to Graves' disease, thyrotoxicosis in general may result in skin sequelae. Starting in the 1950s, there were attempts to use parenteral and topical tri-iodothyronine $\left(\mathrm{T}_{3}\right)$ to treat pretibial myxedema in Graves' patients [4-7]. In all cases, lesions improved with topical or intralesional steroids which ended further study of thyroid hormone action. At that time, it was noted that topical thyroxine $\left(\mathrm{T}_{4}\right)$ stimulated hair growth and pigmentation in cows [8].

\section{Direct Thyroid Hormone Action on Skin Tissues}

Thyroid hormone action on skin is mediated through the thyroid hormone receptor (TR). The three most recognized thyroid hormone binding isoforms of TR have been found in cutaneous tissues [9-12] although methods used do not specifically distinguish which of the three isoforms predominates.

The predominant circulating thyroid hormone is the prohormone, $\mathrm{T}_{4} \cdot \mathrm{T}_{4}$ is converted to the active thyroid hormone, $\mathrm{T}_{3}$, by intracellular thyroid hormone deiodinases $[13,14]$. Two of the enzymes (D1, D2) primarily activate $\mathrm{T}_{4}$ to $\mathrm{T}_{3}$. The third enzyme, $\mathrm{D} 3$, converts $\mathrm{T}_{4}$ to inactive reverse $\mathrm{T}_{3}\left(\mathrm{rT}_{3}\right)$. Investigators have showed conversion of $\mathrm{T}_{4}$ to either $\mathrm{T}_{3}$ or $\mathrm{rT}_{3}$ in cutaneous cultures, demonstrating indirectly the presence of thyroid hormone deiodinases in skin [15-17]. D3 is not expressed significantly in most peripheral tissues. However, assays of enzyme activity suggest that D3 is active in goat epidermis [18], mouse epidermis [19], and human skin in 
vivo $[20,21]$. D2 activity has been demonstrated in cultured human fibroblasts [22]. Neither D1 nor D3 has been found to be active in the dermal fibroblasts, suggesting that D3 expression may be limited to epidermis.

In addition, investigators have identified elements of the hypothalamic-pituitary-thyroid hormone axis in human skin [23-25] and have determined that thyroid hormone receptors mediate skin proliferation and inflammation along with skin response to retinoids $[26,27]$.

2.1. Epidermal Changes. Thyroid hormone accelerates barrier formation by increasing the activity of enzymes in the cholesterol sulfate cycle, and hypothyroidism may hinder the epidermal barrier function [28, 29]. Hypothyroidism also may affect the development of the lamellar granules (Odland bodies), which are vital in the establishment of a normal stratum corneum [30]. In vitro keratinocyte studies have shown that depletion of $\mathrm{T}_{3}$ results in elevated levels of transglutaminase (involved in the formation of the cornified envelope). Further in vitro analysis has suggested that $\mathrm{T}_{3}$ depleted keratinocytes have diminished levels of plasminogen activator [31].

In tissue culture studies, $\mathrm{T}_{3}$ has been shown to directly stimulate proliferation of both epidermal keratinocytes and dermal fibroblasts [32-34]. However, in vivo, skin proliferation directly stimulated by $\mathrm{T}_{3}$ may be offset by inhibiting factors dependent on the systemic $\mathrm{T}_{3}$ [33]. Clinical observations of skin in thyrotoxic patients are complicated by the fact that most cases of thyrotoxicosis are the result of Graves' disease which has an associated finding of autoimmune-mediated glycosaminoglycan deposition in the dermis [35].

2.2. Dermal Changes. The skin tends to be pale in hypothyroidism both because of the dermal mucopolysaccharides and the dermal water content. Changes in hypothyroid dermis can be seen in weeks and reversed in weeks [36, 37]. Hyaluronic acid is the major glycosaminoglycan that accumulates in myxedema [38]. In addition, lack of lymphatic drainage may explain the formation of exudates that are apparent in the myxedematous state [39]. Increased dermal carotene may appear as a yellow hue on the palms, soles, and nasolabial folds. In vitro, thyroid hormone actions on cultured skin fibroblasts include inhibiting synthesis of hyaluronic acid, fibronectin, and collagen [40-42].

The net effect of thyroid hormone on dermal thickness remains the subject of debate. In the past, investigators have reported skin thinning in rats made thyrotoxic with intraperitoneal (IP) $\mathrm{T}_{4}$ [43]. There have been demonstrations both of decreased collagen production in the thyrotoxic animals and increased collagen catabolism in thyrotoxic animals [43, 44]. More recent investigations suggest increased dermal thickness in mice treated with $\mathrm{T}_{3}$, whether topically or intraperitoneally $[32,33]$. There is also a report of increased dermal thickness in mice treated topically with TRIAC (a thyroid hormone analog [45]).

2.3. Hair and Nail Changes. Hale and Ebling demonstrated that intraperitoneal $\mathrm{T}_{4}$ decreased both the resting phase of the hair growth cycle (telogen) and the growth phase of the hair growth cycle (anagen). Although there was an enhanced turnover, the net hair length at any given time was not changed from that of untreated animals [46]. The time to regrowth of hair following epilation was shortened by approximately $10 \%$.

In hypothyroidism, hair can be dry, coarse, brittle, and slow growing. Nails may be thickened, brittle, and slow growing [47]. Diffuse or partial alopecia may be observed along with loss of the lateral third of the eyebrow (madarosis). The alopecia connected to hypothyroidism may be mediated by hormone effects on the initiation as well as the duration of hair growth. There is one report of long, terminal hairs on the backs and extremities of hypothyroid children [48]. The hair disappeared following thyroid hormone replacement, but no mechanism was determined.

Clinically, the hair in thyrotoxicosis may be fine and soft. Nail changes may also occur, characterized by a concave contour and distal onycholysis (Plummer's nails). Diffuse, nonscarring alopecia may also be observed.

Like with epidermal proliferation, hair changes with thyrotoxicosis are different than what might be seen with topically administered thyroid hormone. Mice and rats treated daily for 1-2 weeks with topical $\mathrm{T}_{3}$ had increased hair counts, but mice made thyrotoxic with daily intraperitoneal $\mathrm{T}_{3}$ for 12 weeks had decreased hair counts [33, 44]. Thyrotoxic goats had increased mohair length but decreased fiber diameter [49]. A topical mixture including thyroxine, insulin, and growth hormone increased hair counts over a 6-month treatment period in men with androgenic alopecia [50].

The dryness of hypothyroid skin results from decreased eccrine gland secretion. The mechanism for decreased sweating is not clear although the glands are atrophic on histologic examination [51]. Hypothyroidism has been reported to be a cause of increased sweat electrolytes, requiring differentiation from cystic fibrosis [52].

Hypothyroid patients may sometimes suffer Candida folliculitis. It has been theorized that this may result from decrease sebum production relative to euthyroid persons. The hair follicles may develop a flora with fewer lipophilic organisms, which are replaced by Candida albicans [53].

\section{Potential Use of Thyroid Hormone in the Treatment of Cutaneous Pathology}

Knowledge of cutaneous manifestations of thyrotoxicosis does not predict the direct effects of $\mathrm{T}_{3}$ on skin in vivo. $\mathrm{T}_{3}$ effects on skin depend on route of delivery. Because epidermis expresses the inactivating type 3 deiodinase [19], thyroid hormone action on epidermis in systemic thyrotoxicosis is less than might be predicted. In contrast to the findings with systemic thyrotoxicosis, topical $\mathrm{T}_{3}$ bypasses the inactivating type 3 deiodinase and stimulates epidermal proliferation, dermal thickening, and hair growth $[32,33]$. Topical application of TRIAC (tri-iodothyroacetic acid), the thyroid hormone analog, thickens skin by stimulating production of collagen [45]. Further, topical TRIAC has been shown to reverse the dermal atrophy associated with corticosteroids. 
The importance of thyroid hormone in wound healing had been debated historically. In 1973 and 1974, Mehregan and Zamick reported that oral $\mathrm{T}_{3}$ accelerated the rate of wound healing in euthyroid rats and improved the quality of the wounds $[54,55]$. Scars were smoother in $\mathrm{T}_{3^{-}}$ treated animals. Lennox and Johnston reported accelerated wound healing and increased tensile strength when rats were given supraphysiologic doses of $\mathrm{T}_{4}$ [56]. Pirk et al. reported no change in wound healing with $1.3 \mu \mathrm{g} / 100 \mathrm{mg}$ body weight intraperitoneal $\mathrm{T}_{4}$ in hamsters but increased rate of fracture repair [57]. Ashton and Dekel also reported increased fracture repair rate in mice given $20 \mu \mathrm{g} / 100 \mathrm{mg}$ body weight subcutaneous $\mathrm{T}_{4}$ [58]. In small series, there are reports that hypothyroid patients required thyroid hormone to achieve healing of radiation-induced neck fistulae $[59,60]$. Conversely, Cannon [61] reported that hypothyroidism did not diminish wound strength in pigs, and Ladenson et al. [62] did not detect wound healing deficits in hypothyroid humans.

In contrast, most recent data suggest that topical thyroid hormone may accelerate wound healing rate. Topical application of supraphysiological doses of $\mathrm{T}_{3}$ accelerated wound healing in normal mice and rats [63-65]. A human wound healing formulation has been described that requires $\mathrm{T}_{4}$ in addition to growth hormone and insulin [66].

While direct thyroid hormone action has been demonstrated on cutaneous cell biology, much more study remains to be done. There is a slowly evolving literature to suggest an important role for thyroid hormone in cutaneous wound repair that could be harnessed as a pharmaceutical.

\section{Conflict of Interests}

The author has no conflict of interests relating to this paper.

\section{References}

[1] W. M. Ord, "On myxoedema, term proposed to be applied to an essential condition in the "cretinoid" affection occasionally observed in middle-aged women," Medico-Chirurgical Transactions, vol. 61, pp. 57-78, 1878.

[2] V. Horsley, "The thyroid gland: its relation to the pathology of myxoedema and cretinism, to the question of surgical treatment of goitre, an to the general nutrition of the body," British Medical Journal, vol. 1, pp. 111-115, 1885.

[3] J. Abulkadir, A. Besrat, G. Abraham et al., "Thyrotoxicosis in Ethiopian patients-a prospective study," Transactions of the Royal society of Tropical Medicine and Hygiene, vol. 76, pp. 500502, 1982.

[4] T. A. Warthin and B. B. Boshell, "Pretibial myxedema; treated with local injection of triiodothyronine.," American Medical Association Archives of Internal Medicine, vol. 100, no. 2, pp. 319321, 1957.

[5] J. L. Gabrilove, A. S. Alavarez, and J. Churg, "Generalized and localized (pretibial) myxedema: effect of thyroid analogues and adrenal glucocorticoids," The Journal of Clinical Endocrinology and Metabolism, vol. 20, pp. 825-832, 1960.

[6] T. M. D. Gimlette, "Pretibial myxoedema," British Medical Journal, vol. 2, no. 5195, pp. 348-351, 1960.
[7] B. D. Cohen, R. S. Benua, and R. W. Rawson, "Localized myxedema involving the upper extremities," Archives of Internal Medicine, vol. 111, pp. 641-646, 1963.

[8] A. Berman, "Peripheral effects of L-thyroxine on hair growth and coloration in cattle," Journal of Endocrinology, vol. 20, pp. 288-292, 1960.

[9] M. K. Ahsan, Y. Urano, S. Kato, H. Oura, and S. Arase, "Immunohistochemical localization of thyroid hormone nuclear receptors in human hair follicles and in vitro effect of L-triiodothyronine on cultured cells of hair follicles and skin," Journal of Medical Investigation, vol. 44, no. 3-4, pp. 179-184, 1998.

[10] H. Torma, O. Rollman, and A. Vahlquist, "Detection of mRNA transcripts for retinoic acid, vitamin D3, and thyroid hormone (c-erb-A) nuclear receptors in human skin using reverse transcription and polymerase chain reaction," Acta DermatoVenereologica, vol. 73, no. 2, pp. 102-107, 1993.

[11] N. Billoni, B. Buan, B. Gautier, O. Gaillard, Y. F. Mahé, and B. A. Bernard, "Thyroid hormone receptor $\beta 1$ is expressed in the human hair follicle," British Journal of Dermatology, vol. 142, no. 4, pp. 645-652, 2000.

[12] H. Törmä, T. Karlsson, G. Michaëlsson, O. Rollman, and A. Vahlquist, "Decreased mRNA levels of retinoic acid receptor $\alpha$, retinoid $\mathrm{X}$ receptor $\alpha$ and thyroid hormone receptor $\alpha$ in lesional psoriatic skin," Acta Dermato-Venereologica, vol. 80, no. 1, pp. 4-9, 2000.

[13] A. C. Bianco, D. Salvatore, B. Gereben, M. J. Berry, and P. R. Larsen, "Biochemistry, cellular and molecular biology, and physiological roles of the iodothyronine selenodeiodinases," Endocrine Reviews, vol. 23, no. 1, pp. 38-89, 2002.

[14] A. C. Bianco and B. W. Kim, "Deiodinases: implications of the local control of thyroid hormone action," The Journal of Clinical Investigation, vol. 116, no. 10, pp. 2571-2579, 2006.

[15] S. Refetoff, R. Matalon, and M. Bigazzi, "Metabolism of Lthyroxine (T4) and L-triiodothyronine (T3) by human fibroblasts in tissue culture: evidence for cellular binding proteins and conversion of T4 to T3," Endocrinology, vol. 91, no. 4, pp. 934947, 1972.

[16] T. S. Huang, I. J. Chopra, A. Beredo, D. H. Solomon, and G. N. Chua Teco, "Skin is an active site for the inner ring monodeiodination of thyroxine to $3,3^{\prime}, 5^{\prime}$-triiodothyronine," Endocrinology, vol. 117, no. 5, pp. 2106-2113, 1985.

[17] M. M. Kaplan, C. Pan, P. R. Gordon, J. K. Lee, and B. A. Gilchrest, "Human epidermal keratinocytes in culture convert thyroxine to $3,5,3^{\prime}$-triiodothyronine by type II iodothyronine deiodination: a novel endocrine function of the skin," Journal of Clinical Endocrinology and Metabolism, vol. 66, no. 4, pp. 815822, 1988.

[18] D. Villar, F. Nicol, J. R. Arthur et al., "Type II and type III monodeiodinase activities in the skin of untreated and propylthiouracil-treated cashmere goats," Research in Veterinary Science, vol. 68, no. 2, pp. 119-123, 2000.

[19] M. P. Huang, K. A. Rodgers, R. O’Mara et al., "The thyroid hormone degrading type 3 deiodinase is the primary deiodinase active in murine epidermis," Thyroid, vol. 21, pp. 1263-1268, 2011.

[20] J. P. Schröder-Van Der Elst, D. Van Der Heide, G. M. De Escobar, and M. J. Obregón, "Iodothyronine deiodinase activities in fetal rat tissues at several levels of iodine deficiency: a role for the skin in 3,5,3' -triiodothyronine economy?" Endocrinology, vol. 139, no. 5, pp. 2229-2234, 1998. 
[21] F. Santini, P. Vitti, L. Chiovato et al., "Role for inner ring deiodination preventing transcutaneous passage of thyroxine," Journal of Clinical Endocrinology and Metabolism, vol. 88, no. 6, pp. 2825-2830, 2003.

[22] A. M. Dumitrescu, X. H. Liao, M. S. Y. Abdullah et al., "Mutations in SECISBP2 result in abnormal thyroid hormone metabolism," Nature Genetics, vol. 37, no. 11, pp. 1247-1252, 2005.

[23] A. Slominski, J. Wortsman, L. Kohn et al., "Expression of hypothalamic-pituitary-thyroid axis related genes in the human skin," Journal of Investigative Dermatology, vol. 119, no. 6, pp. 1449-1455, 2002.

[24] E. Bodó, B. Kany, E. Gáspár et al., "Thyroid-stimulating hormone, a novel, locally produced modulator of human epidermal functions, is regulated by thyrotropin-releasing hormone and thyroid hormones," Endocrinology, vol. 151, no. 4, pp. 1633-1642, 2010.

[25] R. Paus, "Exploring the "thyroid-skin connection" : concepts, questions, and clinical relevance," Journal of Investigative Dermatology, vol. 130, pp. 93-101, 2010.

[26] C. Contreras-Jurado, L. García-Serrano, M. Gómez-Ferrería, C. Costa, J. M. Paramio, and A. Aranda, "The thyroid hormone receptors as modulators of skin proliferation and inflammation," The Journal of Biological Chemistry, vol. 286, no. 27, pp. 24079-24088, 2011.

[27] L. Garcia-Serrano, M. A. Gomez-Ferreria, C. Contrera-Jurado, C. Segrelles, J. M. Paramio, and A. Aranda, "The thyroid hormone receptors modulate the skin response to retinoids," PLoS ONE, vol. 6, Article ID e23825, 2011.

[28] R. M. Rosenberg, R. R. Isseroff, V. A. Ziboh, and A. C. Huntley, "Abnormal lipogenesis in thyroid hormone-deficient epidermis," Journal of Investigative Dermatology, vol. 86, no. 3, pp. 244-248, 1986.

[29] K. Hanley, Y. Jiang, C. Katagiri, K. R. Feingold, and M. L. Williams, "Epidermal steroid sulfatase and cholesterol sulfotransferase are regulated during late gestation in the fetal rat," Journal of Investigative Dermatology, vol. 108, no. 6, pp. 871-875, 1997.

[30] K. Hanley, U. P. Devaskar, S. J. Hicks et al., "Hypothyroidism delays fetal stratum corneum development in mice," Pediatric Research, vol. 42, no. 5, pp. 610-614, 1997.

[31] R. R. Isseroff, K. T. Chun, and R. M. Rosenberg, "Triiodothyronine alters the cornification of cultured human keratinocytes," British Journal of Dermatology, vol. 120, no. 4, pp. 503-510, 1989.

[32] J. D. Safer, L. M. Fraser, S. Ray, and M. F. Holick, “Topical triiodothyronine stimulates epidermal proliferation, dermal thickening, and hair growth in mice and rats," Thyroid, vol. 11, no. 8, pp. 717-724, 2001.

[33] J. D. Safer, T. M. Crawford, L. M. Fraser et al., "Thyroid hormone action on skin: diverging effects of topical versus intraperitoneal administration," Thyroid, vol. 13, no. 2, pp. 159-165, 2003.

[34] P. J. A. Holt, "In vitro responses of the epidermis to triiodothyronine," Journal of Investigative Dermatology, vol. 71, no. 3, pp. 202-204, 1978.

[35] P. J. A. Holt and R. Marks, "The epidermal response to change in thyroid status," Journal of Investigative Dermatology, vol. 68, no. 5, pp. 299-301, 1977.

[36] M. J. Reuter, "Histopathology of the skin in myxedema," Archives of Dermatology and Syphilology, vol. 24, pp. 55-71, 1931.

[37] J. L. Gabrilove and A. W. Ludwig, "The histogenesis of myxedema," The Journal of Clinical Endocrinology and Metabolism, vol. 17, no. 8, pp. 925-932, 1957.
[38] T. J. Smith, R. S. Bahn, and C. A. Gorman, "Connective tissue, glycosaminoglycans, and diseases of the thyroid," Endocrine Reviews, vol. 10, no. 3, pp. 366-391, 1989.

[39] H. H. Parving, J. M. Hansen, and S. L. Nielsen, "Mechanisms of edema formation in myxedema-increased protein extravasation and relatively slow lymphatic drainage," The New England Journal of Medicine, vol. 301, no. 9, pp. 460-465, 1979.

[40] T. J. Smith, Y. Murata, A. L. Horwitz, L. Philipson, and S. Refetoff, "Regulation of glycosaminoglycan synthesis by thyroid hormone in vitro," The Journal of Clinical Investigation, vol. 70, no. 5, pp. 1066-1073, 1982.

[41] Y. Murata, P. Ceccarelli, S. Refetoff, A. L. Horwitz, and N. Matsui, "Thyroid hormone inhibits fibronectin synthesis by cultured human skin fibroblasts," Journal of Clinical Endocrinology and Metabolism, vol. 64, no. 2, pp. 334-339, 1987.

[42] C. De Rycker, J. L. Vandalem, and G. Hennen, "Effects of 3,5,3' triiodothyronine on collagen synthesis by cultured human skin fibroblasts," FEBS Letters, vol. 174, no. 1, pp. 34-37, 1984.

[43] C. W. Fink, J. L. Ferguson, and J. D. Smiley, "Effect of hyperthyroidism and hypothyroidism on collagen metabolism," The Journal of Laboratory and Clinical Medicine, vol. 69, no. 6, pp. 950-959, 1967.

[44] K. I. Kivirikko, O. Laitinen, J. Aer, and J. Halme, "Metabolism of collagen in experimental hyperthyroidism and hypothyroidism in the rat," Endocrinology, vol. 80, no. 6, pp. 1051-1061, 1967.

[45] J. Faergemann, T. Särnhult, E. Hedner et al., "Dose-response effects of tri-iodothyroacetic acid (Triac) and other thyroid hormone analogues on glucocorticoid-induced skin atrophy in the haired mouse," Acta Dermato-Venereologica, vol. 82, no. 3, pp. 179-183, 2002.

[46] P. A. Hale and F. J. Ebling, "The effect of a single epilation on successive hair eruptions in normal and hormone-treated rats," Journal of Experimental Zoology, vol. 207, no. 1, pp. 49-71, 1979.

[47] G. E. Mullin and J. S. Eastern, "Cutaneous signs of thyroid disease," American Family Physician, vol. 34, no. 4, pp. 93-98, 1986.

[48] W. H. Perloff, "Hirsutism; a manifestation of juvenile hypothyroidism," Journal of the American Medical Association, vol. 157, no. 8, pp. 651-652, 1955.

[49] R. Puchala, I. Prieto, V. Banskalieva, A. L. Goetsch, M. Lachica, and T. Sahlu, "Effects of bovine somatotropin and thyroid hormone status on hormone levels, body weight gain, and mohair fiber growth of Angora goats," Journal of Animal Science, vol. 79, no. 11, pp. 2913-2919, 2001.

[50] E. S. Lindenbaum, A. L. Feitelberg, M. Tendler et al., "Pilot study of a novel treatment for androgenetic alopecia using enriched cell culture medium: clinical trials," Dermatology Online Journal, vol. 9, article 4, 2003.

[51] M. A. Means and R. L. Dobson, "Cytological changes in the sweat gland in hypothyroidism," Journal of the American Medical Association, vol. 186, pp. 113-115, 1963.

[52] L. Squires and T. F. Dolan, "Abnormal sweat chloride in autoimmune hypothyroidism," Clinical Pediatrics, vol. 28, no. 11, pp. 535-536, 1989.

[53] S. Dekio, C. Imaoka, and J. Jidoi, "Candida folliculitis associated with hypothyroidism," British Journal of Dermatology, vol. 117, no. 5, pp. 663-664, 1987.

[54] P. Zamick and A. H. Mehregan, "Effect of 1-tri-iodothyronine on marginal scars of skin grafted burns in rats," Plastic and Reconstructive Surgery, vol. 51, no. 1, pp. 71-75, 1973. 
[55] A. H. Mehregan and P. Zamick, "The effect of triiodothyronine in healing of deep dermal burns and marginal scars of skin grafts. A histologic study," Journal of Cutaneous Pathology, vol. 1, no. 3, pp. 113-116, 1974.

[56] J. Lennox and I. D. Johnston, "The effect of thyroid status on nitrogen balance and the rate of wound healing after injury in rats," British Journal of Surgery, vol. 60, no. 4, p. 309, 1973.

[57] F. W. Pirk, T. M. El-Attar, and G. D. Roth, "Effect of analogues of steroid and thyroxine hormones on wound healing in hamsters," Journal of Periodontal Research, vol. 9, no. 5, pp. 290-297, 1974.

[58] I. K. Ashton and S. Dekel, "Fracture repair in the snell dwarf mouse," British Journal of Experimental Pathology, vol. 64, no. 5, pp. 479-486, 1983.

[59] M. M. V. Alexander, J. T. Zajtchuk, and R. L. Henderson, "Hypothyroidism and wound healing. Occurrence after head and neck radiation and surgery," Archives of Otolaryngology, vol. 108, no. 5, pp. 289-291, 1982.

[60] Y. P. Talmi, Y. Finkelstein, and Y. Zohar, "Pharyngeal fistulas in postoperative hypothyroid patients," Annals of Otology, Rhinology \& Laryngology, vol. 98, no. 4, pp. 267-268, 1989.

[61] C. R. Cannon, "Hypothyroidism in head and neck cancer patients: experimental and clinical observations," Laryngoscope, vol. 104, no. 11, pp. 1-21, 1994.

[62] P. W. Ladenson, A. A. Levin, E. C. Ridgway, and G. H. Daniels, "Complications of surgery in hypothyroid patients," American Journal of Medicine, vol. 77, no. 2, pp. 261-266, 1984.

[63] J. D. Safer, T. M. Crawford, and M. F. Holick, "Topical thyroid hormone accelerates wound healing in mice," Endocrinology, vol. 146, no. 10, pp. 4425-4430, 2005.

[64] M. Tarameshloo, M. Norouzian, S. Zarein-Dolob, M. Dadpay, and R. Gazor, "A comparative study of the effects of topical application of Aloe vera, thyroid hormone and silver sulfadiazine on skin wounds in Wistar rats," Laboratory Animal Research, vol. 28, pp. 17-21, 2012.

[65] R. Kassem, Z. Liberty, M. Babaev, H. Trau, and O. Cohen, "Harnessing the skin-thyroid connection for wound healing: a prospective controlled trial in guinea pigs," Clinical and Experimental Dermatology, vol. 37, pp. 850-856, 2012.

[66] E. S. Lindenbaum, Y. H. Shai, Y. Ullmann et al., "Stimulated healing of recalcitrant wounds by topical application of enriched cell culture medium: a clinical report," Plastic and Reconstructive Surgery, vol. 108, no. 1, pp. 104-113, 2001. 


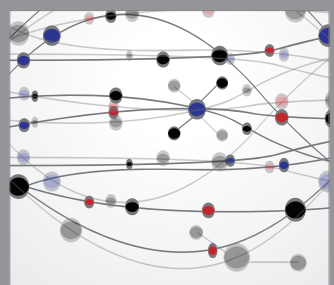

The Scientific World Journal
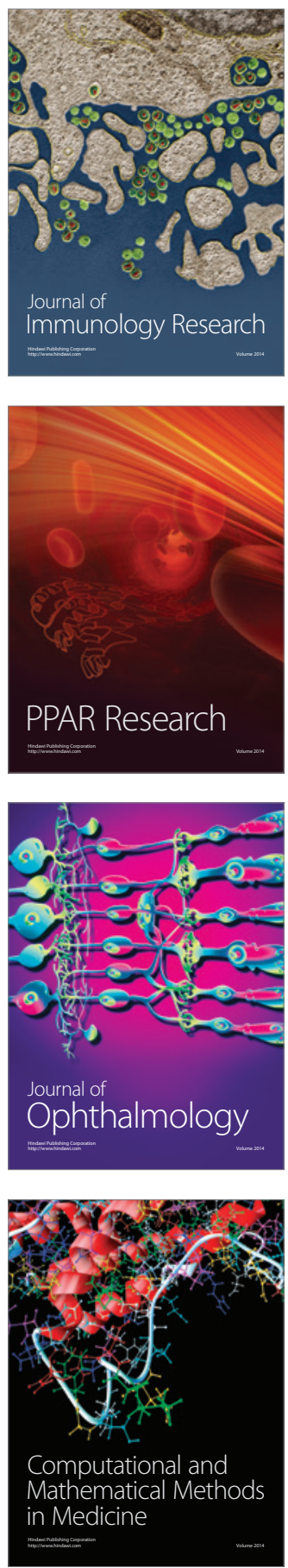

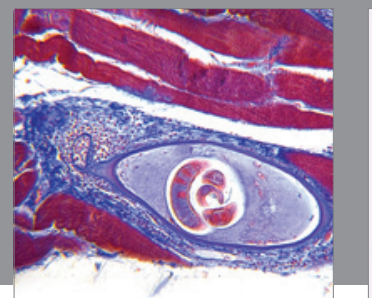

Gastroenterology

Research and Practice
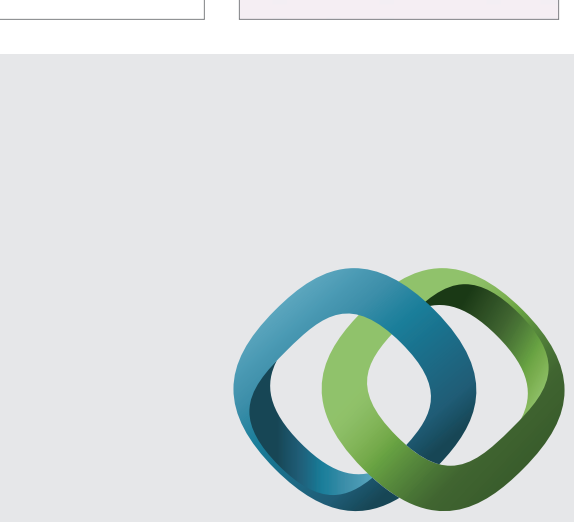

\section{Hindawi}

Submit your manuscripts at

http://www.hindawi.com
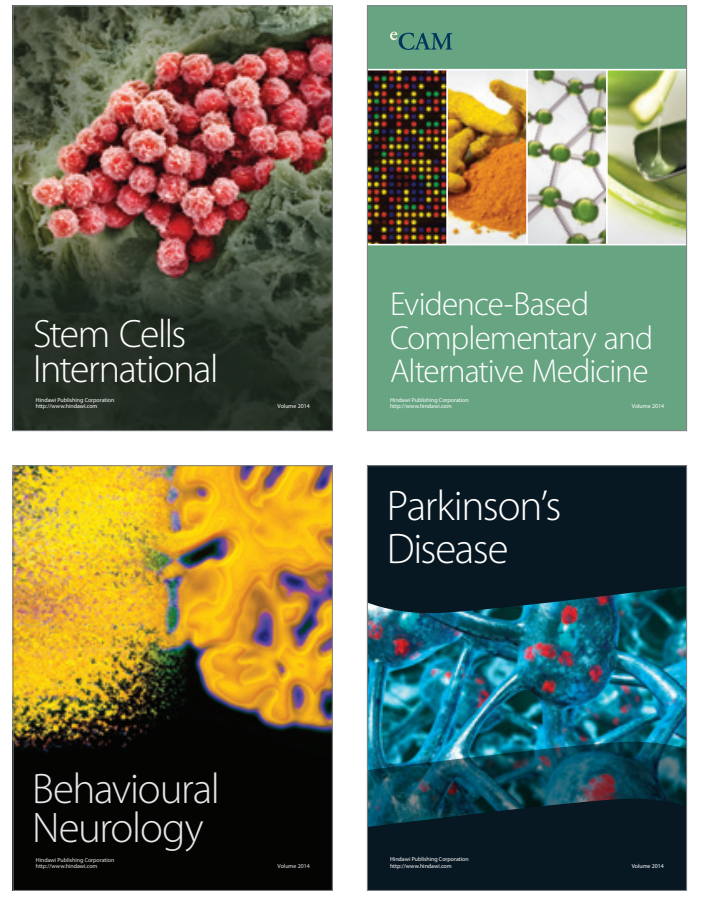
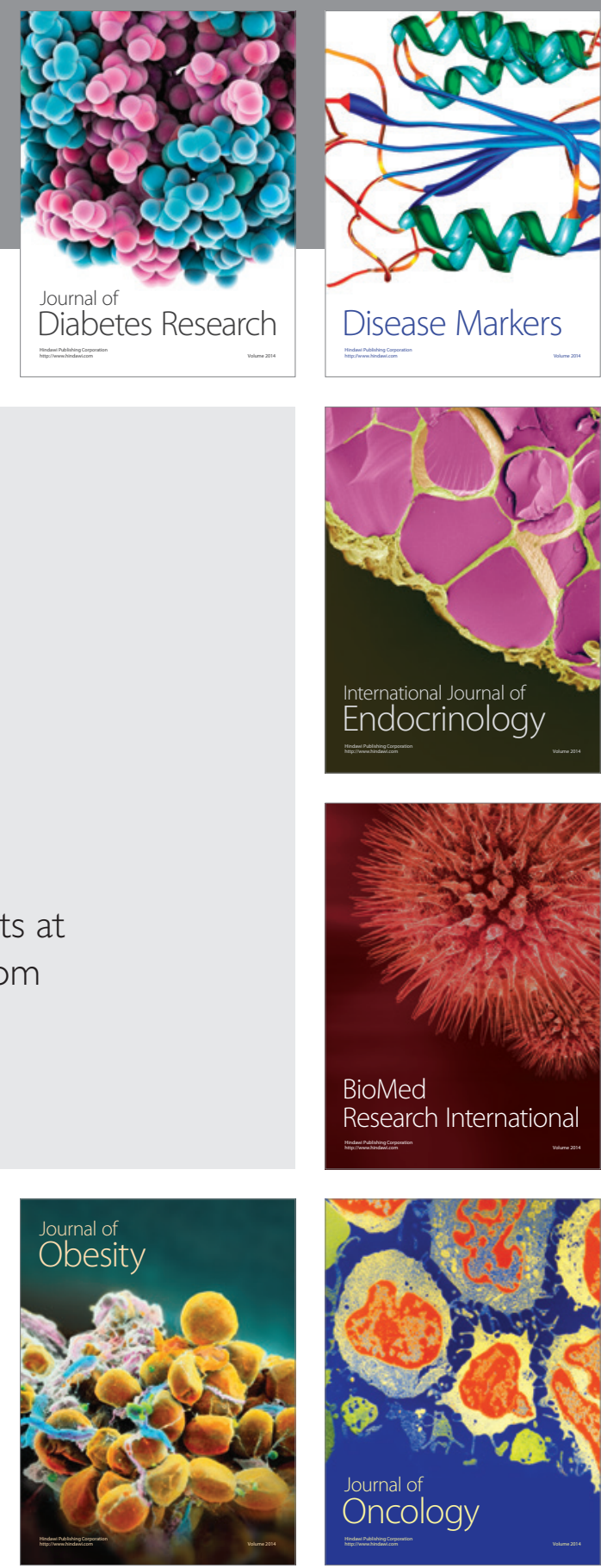

Disease Markers
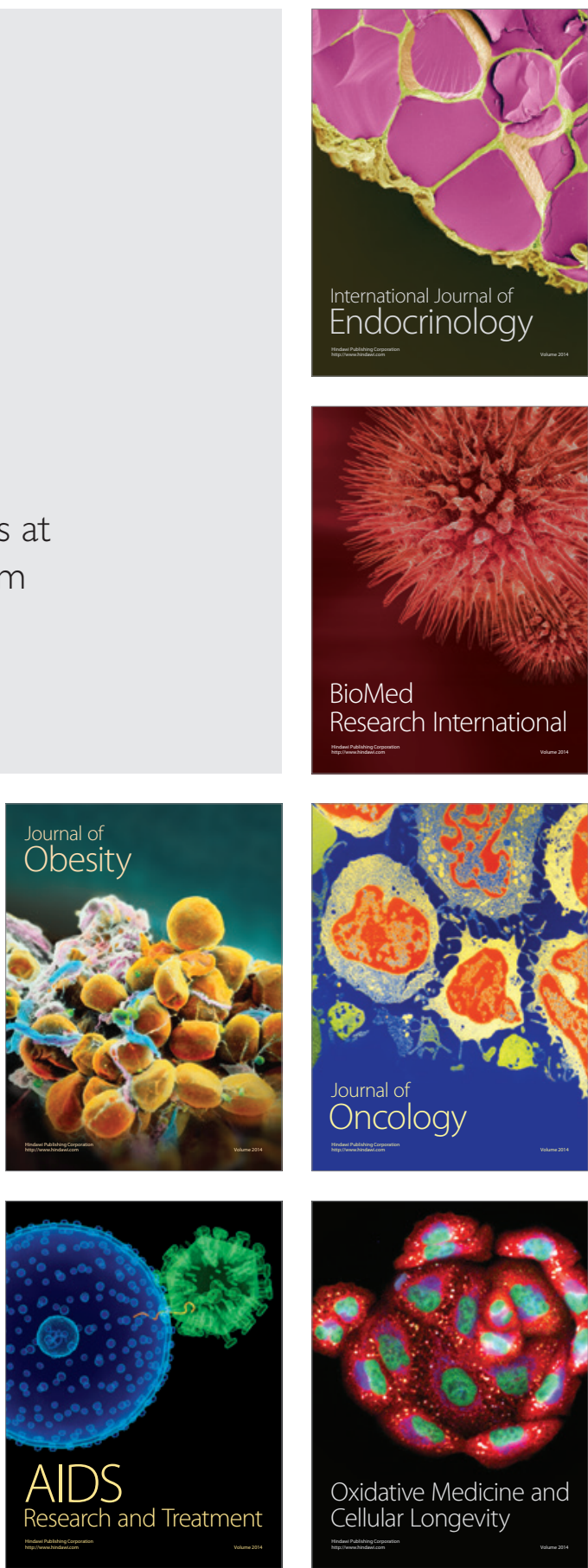